\title{
New Perspectives on the Structure and Function of the Normal and Diabetic $\beta$-cell
}

\author{
Claes Hellerström, Décio L. Eizirik, Nils Welsh, Åke Sjöholm, Leif Jansson, \\ Carina Svensson, Eva Strandell, Olle Korsgren, Zuo-Qiang Li, Arne Andersson \\ and Stellan Sandler \\ Department of Medical Cell Biology, Uppsala University, Uppsala, Sweden
}

The pancreatic B-cell has the unique capability to express the insulin gene and to synthesize, store and release insulin exactly according to the needs of the body. In a broad sense the $B$-cell can be regarded as a biological sensor of circulating metabolic substrates, which are controlled by a feed-back system involving insulin secretion. Insulin is synthesized on the endoplasmic reticulum in the form of preproinsulin which is rapidly cleaved to proinsulin, transported to the Golgi zone and packed into secretory granules. Proinsulin is converted into C-peptide and biologically active insulin which is stored in the granules until released as a result of one or several specific signals reaching the B-cell. The most important of these is an elevation of the blood glucose level, which causes an insulin response directly proportional to the glucose concentration. This process is of decisive importance for the short-term regulation of the blood glucose level. Of equal importance, however, is the total Bcell mass, which determines the capacity for insulin production in the long-term and is the result of an adaptive growth process.

A deficient insulin production in relation to the insulin requirement is a common denominator of all types of diabetes. This state may be induced by the action of toxins, viruses or autoimmune assaults on the B-cell or, perhaps, exhaustion from a long-standing functional demand on the insulin production. There is still poor knowledge on the various states of insulin deficiency and a deeper insight into the underlying mechanisms would greatly enhance the attempts to find a treatment or cure for diabetes and also to introduce measures for complete prevention of the disease. The present paper will summarize some recent observations on factors regulating insulin production and mechanisms of $B$-cell proliferation and degeneration.

\section{A. INSULIN BIOSYNTHESIS}

Control of insulin gene expression is achieved through synthesis, processing, transport and degradation of insulin mRNA. The islet content of insulin mRNA is 
closely regulated and can vary more than 10-fold during culture at different glucose concentrations (9). Also in vivo insulin mRNA contents are controlled by the extracellular glucose concentration, in that the insulin mRNA contents decrease during fasting and increase during glucose infusion (26). The enhancing effect of glucose is due to a combination of stimulation of both the synthesis and the stability of the messenger for insulin $(47,72)$. Since glucose needs to be metabolized to exert its effects, it is reasonable to assume that factors produced by the oxidative metabolism may mediate the glucose effect. In addition, CAMP has been shown to exert a selective effect on the transcription of the insulin gene (47). By using inhibitors of polyamine biosynthesis it was recently shown that increased synthesis of spermidine and spermine is necessary for glucose stimulated insulin gene expression (80). The requirement for polyamines was specific for insulin mRNA, since total RNA synthesis and turnover were not affected by the inhibitors. The effect of the inhibitors of polyamine biosynthesis on insulin mRNA contents was counteracted by cycloheximide. This suggests that polyamines increase insulin mRNA contents by enhancing the stability of the messenger rather than increasing the transcription rate. Besides glucose, which is the main modulator of insulin mRNA contents, other substances have been shown to influence the metabolism of insulin mRNA and the list of these substances is rapidly growing (76).

Interestingly, when insulin gene expression is assessed in various animal models for non-insulin-dependent diabetes, a correlation between hyperglycemia and decreased insulin mRNA is usually observed $(71,76)$. However, it is not clear whether a decreased insulin mRNA content is a cause or merely a consequence of the glucose intolerance observed in these diabetes models. When islets from mildly diabetic rats treated neonatally with streptozotocin are cultured in vitro, a restoration of insulin mRNA contents and insulin biosynthesis rates was observed at both high and low glucose concentrations (81). This may indicate that the islets did not possess an inherent defect in the capacity to produce insulin and that hyperglycemia in vivo was not the sole cause of the insulin mRNA deficiency. Further studies are thus necessary to assess the role of expression of the insulin gene in non-insulin dependent diabetes mellitus (NIDDM).

Translation of insulin mRNA involves initiation, translocation to the endoplasmic reticulum (via the so called signal recognition particle (SRP/SRP-receptor mechanism), elongation and termination (73). Glucose exerts a rapid and powerful stimulation of the synthesis of insulin, an effect which is specific for insulin and does not require increased synthesis of insulin mRNA (36). The initiation of protein biosynthesis is considered as one of the major regulatory events and this process is mainly regulated by islet protein phosphorylation (33). It was previously shown that this process is stimulated by nutrients and theophylline (78). The latter observation suggests that a cAMP-dependent protein kinase acts as an intracellular mediator of this action. When the formation of the initiation complex has occurred, the SRP binds 
to the signal sequence and the complex is translocated to the endoplasmic reticulum. Also this process was found to be stimulated by nutrients, but not by theophylline, leading to a preferential stimulation of insulin biosynthesis (78). It was recently shown that both the SRP and its receptor contain subunits which bind GTP (5). In view of this, we introduced a non-hydrolyzable GTP-analogue into islet cells by means of the liposome technique, and observed a specific increase in insulin biosynthesis and an increased translocation of insulin mRNA to the endoplasmic reticulum (84). This suggests that GTP-binding proteins regulate this process and that glucose exerts its effect by increasing the cytosolic GTP/GDP ratio.

\section{B. INSULIN RELEASE}

The mechanism for insulin release is finely tuned by a complex set of incoming signals; e.g. nutrients and hormones carried via the blood, neuronal input from surrounding nerve terminals, and paracrine influences from neighbouring islet cells. An additional factor of importance for an adequate hormone release is the islet vascular organization and blood flow. The islets have numerous fenestrated capillaries, and the blood seems to flow from the centrally located B-cells towards the peripheral mantle of non- $\beta$ cells (57). Normally the islet blood perfusion is proportional to the degree of insulin release, mainly due to the fact that glucose selectively stimulates the islet blood flow by a mechanism mediated via the central nervous system (37). However, since a $50 \%$ reduction in islet blood flow can still be associated with an increased insulin release (38), it is likely that the blood perfusion of the islets normally imposes no restrictions on the insulin release.

The intracellular events governing the release of insulin have been the subject of intensive investigation during recent years. As a result of these studies evidence is now accumulating that insulin secretion is closely regulated by different signaling systems, encompassing phosphoinositide hydrolysis, increases in cytosolic $\mathrm{Ca}^{2+}$ and cyclic AMP generation.

Glucose plays a key role in insulin release and is capable of potentiating the action of other secretagogues (45). The secretory response to ambient glucose concentrations exceeding $5 \mathrm{mM}$ is dose-dependent and sigmoidal, reaching half-maximal stimulation at $8 \mathrm{mM}$ and leveling off at $17 \mathrm{mM}$. Metabolism of the sugar seems to be necessary for its insulin releasing effect, as inferred from the combined observations of an attenuated secretory response to glucose by mannoheptulose, which inhibits glycolysis, and the lack of insulin release in the presence of non-metabolizable sugars (34). The major route of glucose metabolism involves its initial phosphorylation by hexokinase and glucokinase, further conversion into pyruvate in the glycolytic pathway and subsequent oxidative metabolism in the mitochondria. Interestingly, islet $B$-cells seem to be organized to favour the mitochondrial oxidative 
events, which yields the major fraction of the energy derived from the glucose catabolism (61). The ATP thus generated will lead to an increase in the total islet ATP content, with the most conspicuous increase occurring in the cytosol (34).

Recent findings have revealed the existence in the B-cell plasma membrane of ATPregulated $\mathrm{K}^{+}$-channels (G-channels) which control transmembrane $\mathrm{K}^{+}$fluxes (11). ATP may thus provide a link between glucose metabolism and changes in B-cell electrical activity elicited by glucose. More specifically, the ATP produced by glucose metabolism may close the G-channels resulting in depolarization and subsequent influx of $\mathrm{Ca}^{2+}$ through voltage-activated $\mathrm{Ca}^{2+}$-channels. This influx of $\mathrm{Ca}^{2+}$ increases the cytosolic $\mathrm{Ca}^{2+}$ concentration, an event triggering secretory granule translocation and the exocytotic release of insulin (28). The effects of $\mathrm{Ca}^{2+}$ appear to be largely mediated by a $\mathrm{Ca}^{2+-d e p e n d e n t ~ r e g u l a t o r y ~ p r o t e i n, ~ c a l m o d u l i n . ~ T h e ~ s i g n i f i c a n c e ~ o f ~}$ these changes in $\mathrm{Ca}^{2+}$ are underscored by the observations that glucose-regulated insulin release could be inhibited by calmodulin antagonists or blockers of voltageactivated $\mathrm{Ca}^{2+}$-channels (34).

Another means of increasing cytosolic $\mathrm{Ca}^{2+}$ is via mobilization of $\mathrm{Ca}^{2+}$ from intracellular stores. This phenomenon has attracted great interest since the discovery of inositol trisphosphate $\left(\mathrm{IP}_{3}\right)$ as a second messenger, conveying receptor-mediated signals and capable of releasing $\mathrm{Ca}^{2+}$ from the endoplasmic reticulum (6). $\mathrm{IP}_{3}$ is formed during phospholipase C-catalyzed hydrolysis of phosphoinositol phospholipids present in the plasma membrane. $\mathrm{IP}_{3}$ then diffuses into the cytosol and binds to a specific receptor on the endoplasmic reticulum. This event, still awaiting detailed characterization, results in the liberation of $\mathrm{Ca}^{2+}$ from the endoplasmic reticulum. The second product of the phospholipase $\mathrm{C}$-mediated reaction is diacylglycerol, which functions as an endogenous activator of the $\mathrm{Ca}^{2+}$ and phospholipid-dependent protein kinase C (39). Insulin producing cells transfected with an activated $\mathrm{c}-\mathrm{Ha}$-ras oncogene increased their activities of both phospholipase $C$ and protein kinase $C(4)$. The importance of protein kinase $C$ in the regulation of insulin secretion has been explored by the use of tumor-promoting phorbol esters, which are potent stimulators of protein kinase $\mathrm{C}$ when added acutely. It has been found that phorbol esters are able to increase insulin secretion as well as B-cell protein kinase $\mathrm{C}$ activity despite a lowering in the cytosolic $\mathrm{Ca}^{2+}$ concentration (2). Moreover, the endogenous $B$-cell protein kinase $C$ activity was increased by exposure to a high glucose concentration (2). However, when protein kinase $C$ was downregulated by prolonged phorbol ester treatment, there was still an intact response to glucose with respect to insulin release and increase in cytosolic $\mathrm{Ca}^{2+}(2)$. Thus, these results imply that protein kinase $C$ activation apparently is of no major regulatory importance in glucose-regulated insulin release. Nevertheless, protein kinase $C$ activation may be required for amplification of the insulin release in response to other secretagogues by sensitizing the stimulus-secretion coupling to $\mathrm{Ca}^{2+}$. Sympathetic as well as parasympathetic nerve fibers are abundant in the pancreatic islets (34). 
Whereas sympathetic stimulation, or the addition of sympathetic neurotransmitters epinephrine or norepinephrine, inhibits insulin release via adrenergic receptors, parasympathetic stimulation enhances insulin secretion (34). Likewise, insulin release can be directly stimulated by addition of the parasympathetic transmittor acetylcholine or its non-hydrolyzable analogue carbamylcholine. These latter substances are believed to exert their action via muscarinic receptors coupled to phospholipase $\mathrm{C}$ via a GTP-binding protein, and thus provoke insulin secretion by the sequential release of $\mathrm{IP}_{3}$ and $\mathrm{Ca}^{2+}$.

In fetal $B$-cells the stimulus-secretion coupling displays a poor sensitivity to glucose. Indirect evidence suggest that the immature insulin response reflects a deficient coupling between substrate metabolism and transmembrane $\mathrm{K}^{+}$fluxes. The issue of whether this deficiency resides at the level of metabolism or ion transport was recently addressed (55). The outcome of that study indicated that the ATP-regulated $\mathrm{K}^{+}$. channels (G-channels) of the fetal B-cell did not close when glucose was added but otherwise showed a similar sensitivity to ATP as those of adult B-cells. Similarly, no differences in the characteristics of the voltage-activated $\mathrm{Ca}^{2+}$-channels were detected between fetal and adult B-cells. On the other hand, fetal B-cells exhibited an immature glucose metabolism in that they failed to increase their ATP content following exposure to a high glucose concentration. A later study pointed to a lower cellular content of the mRNA for the adenine nucleotide translocator, which determines the rate of ADP-ATP flux between the mitochondria and the cytosol, as one possible cause of the immaturity of the ATP metabolism in fetal B-cells (79). All in all, these observations suggest that the deficient secretory response to glucose in the fetal $B$-cell reflects an immature mitochondrial glucose metabolism resulting in an inability to close the otherwise normal G-channel.

\section{B-CELL PROLIFERATICN}

The capacity for insulin production in the body is a function of both the number of Bcells and the ability of individual $B$-cells to release insulin in response to various secretagogues. The total $B$-cell number reflects the balance between additions of new B-cells through cell replication and the loss of senescent or injured B-cells through cell death. It is conceivable that either an increased B-cell loss or a decreased regeneration can lead to glucose intolerance and eventual diabetes. Conversely, the induction of an increased growth of the B-cell mass may ameliorate a diabetic state or even prevent the onset of the disease. More insight into the regulation of $\beta$-cell replication would therefore be instrumental for a better understanding of the cause and natural history of any form of diabetes mellitus.

The B-cell replication is substrate dependent and glucose is a strong stimulator of this process throughout postnatal life $(29,31)$. The control of the replicatory activity is 
exerted through regulation of the so called proliferative compartment of the whole cell population (67). This measure is defined as the fraction of the whole cell population which is able to divide and progress through the cell cycle. It has been shown that the size of the proliferative compartment is directly proportional to the extracellular glucose concentration and that even in the fetal B-cells it comprises less than $10 \%$ at any glucose level. Knowledge on the size of the proliferative compartment also provides a possibility to calculate the cell birth rate and the time it takes for a cell population to reach a given number and volume. In the case of the B-cells a doubling of the total mass at maximal glucose stimulation in the adult rat would take not more than about 30 days (31).

The B-cell replication is regulated not only by glucose but also by several growth promoting peptides. Growth hormone $(\mathrm{GH})$ has been extensively studied in this context and its stimulatory effects on both B-cell replication and insulin production have been well documented $(48,68)$. The ability of $\mathrm{GH}$ to stimulate, in several tissues, the local production of somatomedin C/insulin-like growth factor 1 (IGF-1) led to a search for this growth factor also in the islet B-cells. Addition of $\mathrm{GH}$ to islets maintained in tissue culture stimulated release of IGF-1 from these islets (69). This latter peptide also stimulated B-cell replication when added to islets in vitro and the replication induced by $\mathrm{GH}$ could be partially abolished by addition of a monoclonal antibody towards IGF-1 (69). GH therefore seems to stimulate B-cell replication via a mechanism involving IGF-1. However, an additional peptide, namely platelet-derived growth factor (PDGF), has a weak stimulating effect on the islet cells (70). Also epidermal growth factor (EGF) and fibroblast growth factor (FGF) have been shown to stimulate B-cell replication albeit to a lesser extent than GH or IGF-1 (49). A recent approach to study $B$-cell replication has been to transfect these cells with various growth promoting genes, such as (proto)oncogenes, and then determine their rates of DNA synthesis. It was observed in this context that an oncogene coding for a tyrosine kinase, v-src, and a combination of C-myc and c-Ha-ras stimulated islet DNA synthesis (74). Furthermore, coexpression on the islet cells of PDGF B-chain and the PDGF $B$ receptor also stimulated DNA synthesis (76).

Growth of the $B$-cell mass in vivo is normally adaptive, i.e. the amount of insulin producing cells adapts to the insulin need of the body. This is exemplified by the physiologic expansion of the B-cell mass during pregnancy $(30)$ or the enormous growth of the B-cells associated with the hyperphagia and insulin resistance which characterize the recessively inherited obese-hyperglycemic syndrome in the mouse (obob ) (10). However, a failure of the B-cell proliferation to meet the insulin needs may lead to overt diabetes. This is amply demonstrated when the ob-gene is introduced in certain mouse strains with a deficient capacity for an adaptive B-cell growth in response to an increased insulin demand (10). In such animals the B-cells fail to respond with adequate proliferation to the increased functional demand imposed by the development of obesity and insulin resistance in the homozygotic 
animals, which develop severe hyperglycemia. There is indirect evidence to suggest that a similar mechanism may operate also in obese patients with NIDDM. Morphological studies show that these patients have a significantly smaller mass of Bcells than obese individuals with a normal blood glucose regulation (40). If this reflects a deficient adaptive $B$-cell growth, then an inherited restriction on the ability of B-cells to proliferate may represent a significant pathogenetic factor in the development of NIDDM.

\section{B-CELL DEGENERATION}

There is general agreement that the onset of insulin-depentent diabetes mellitus (IDDM) is preceded by a sub-clinical period, often lasting for years (13). This period is characterized by the presence of circulating islet cell antibodies, abnormalities of cell mediated immunity and the progressive loss of the insulin response to intravenous glucose, while the response to secretagogues like glucagon and arginine is relatively preserved. As a whole, these findings suggest a slow and progressive impairment and destruction of the $B$-cells, probably due to an autoimmune response directed towards the B-cells. However, the cellular and molecular mechanisms behind this assault still remain to be clarified. Furthermore, little is known about adaptive and defense mechanisms triggered by the $B$-cells after injury.

Studies in vivo of these problems have been hampered by difficulties in dissociating the effects of toxic and/or immunologically mediated B-cell injury from those of the progressive hyperglycaemia, inherent to the IDDM situation. It is of considerable importance to develop in vitro systems in which isolated islets can be exposed to different assaults and subsequently maintained in culture, allowing a detailed study of the different factors outlined above (18).

\section{D.1. Function and metabolism of pancreatic islets following exposure to cytokines}

It has been recently proposed that cytokines, released mainly from macrophages infiltrating the islets, can be one of the key mediators of immune-induced B-cell destruction in IDDM (46). In vitro studies have shown that interleukin-1 (IL-1) is toxic to rat $B$-cells, as evidenced by structural degeneration $(44,57,58)$, inhibition of total protein and proinsulin biosynthesis $(58,62)$, inhibition of insulin release, and a decrease in insulin and DNA contents (58). IL-1 has recently been shown also to be toxic to human $B$-cells in tissue culture (54). These deleterious effects of the cytokine seem to be potentiated by tumor necrosis factor (TNF) $(14,43)$ and interferon- $\gamma(53)$. Also another cytokine, interleukin- 6 , exerts inhibitory actions on the B-cells, but in a way which can be clearly separated from that of IL-1 (60). Interestingly, rat islets exposed to IL-1 for $48 \mathrm{~h}$ present a marked decrease in the glucose-induced insulin 
release, while these cells exhibit a higher insulin release in response to other stimuli, like arginine and compounds able to rise intracellular cAMP $(17,20)$. These islets, therefore, show a pattern of insulin release similar to that observed in the early phases of human IDDM (25). The biochemical mechanisms behind this defective response to glucose may be related to an impaired mitochondrial metabolism $(14,20,59)$. Thus, these cells have a normal glycolytic pathway, as evaluated by the rate of glucose utilization, while there is a severe decrease in their glucose oxidation (Fig. 1). Furthermore, the potentiation by TNF of the actions of IL-1 on the B-cells is accompanied by an increased impairment in glucose oxidation. However, the fact that exposure of pancreatic islets to streptozotocin, a B-cytotoxic agent able to induce long lasting damage to the B-cells $(16,63)$, also induces a preferential impairment in mitochondrial metabolism (Fig. 1) (15) suggests that a defective mitochondrial function is a common response of B-cells after different assaults.

The molecular mechanisms behind the initial IL-1 effects on the B-cells remain to be clarified. Recent data suggest that the cytokine binds to specific surface receptors (27). This is followed by protease activation $(22,82)$, gene transcription and protein translation $(22,35)$. A convincing explanation of the mechanism(s) of action of IL-1 on the pancreatic B-cells will probably require a detailed characterization of which genes are transcribed and which proteins are synthesized immediately after IL-1 exposure.

\section{D.2. The role of hyperalycemia in B-cell dysfunction}

The possibility of a glucose-induced pancreatic B-cell toxicity remains an issue of considerable debate. The basic concept is that the insulin secretory defects observed in NIDDM and in the early phases of IDDM are due to a chronic hyperglycaemic stimulation of a reduced B-cell mass (for reviews see $8,51,54,71$ ). There is an impressive experimental support for this idea, relying mainly on animal models like exposure of islet grafts to a diabetic environment (41), neonatal injection of streptozotocin, partial pancreatectomy and in vivo infusion of glucose $(51,54,71)$. Although there are also several studies suggesting that islet culture in the presence of high glucose can impair insulin secretion (54), other studies failed to reproduce such a phenomenon in vitro $(1,7,66)$, even when long-term exposure of islets to high glucose concentrations was superimposed upon a previous toxic- or immunemediated injury to the islets $(19,23)$. Moreover, it has been shown that sorbitol, which may accumulate in several tissues of hyperglycemic animals, does not accumulate in islet cells even at very high ambient glucose concentration (Zuo-qiang-Li et al., to be published). When studying the potential deleterious effects of high glucose in vitro, it is crucial to demonstrate that the culture conditions are able to properly support the function of the islets at near-physiological glucose concentrations. In two recent studies it was shown that, under adequate culture conditions, mouse and rat islets 


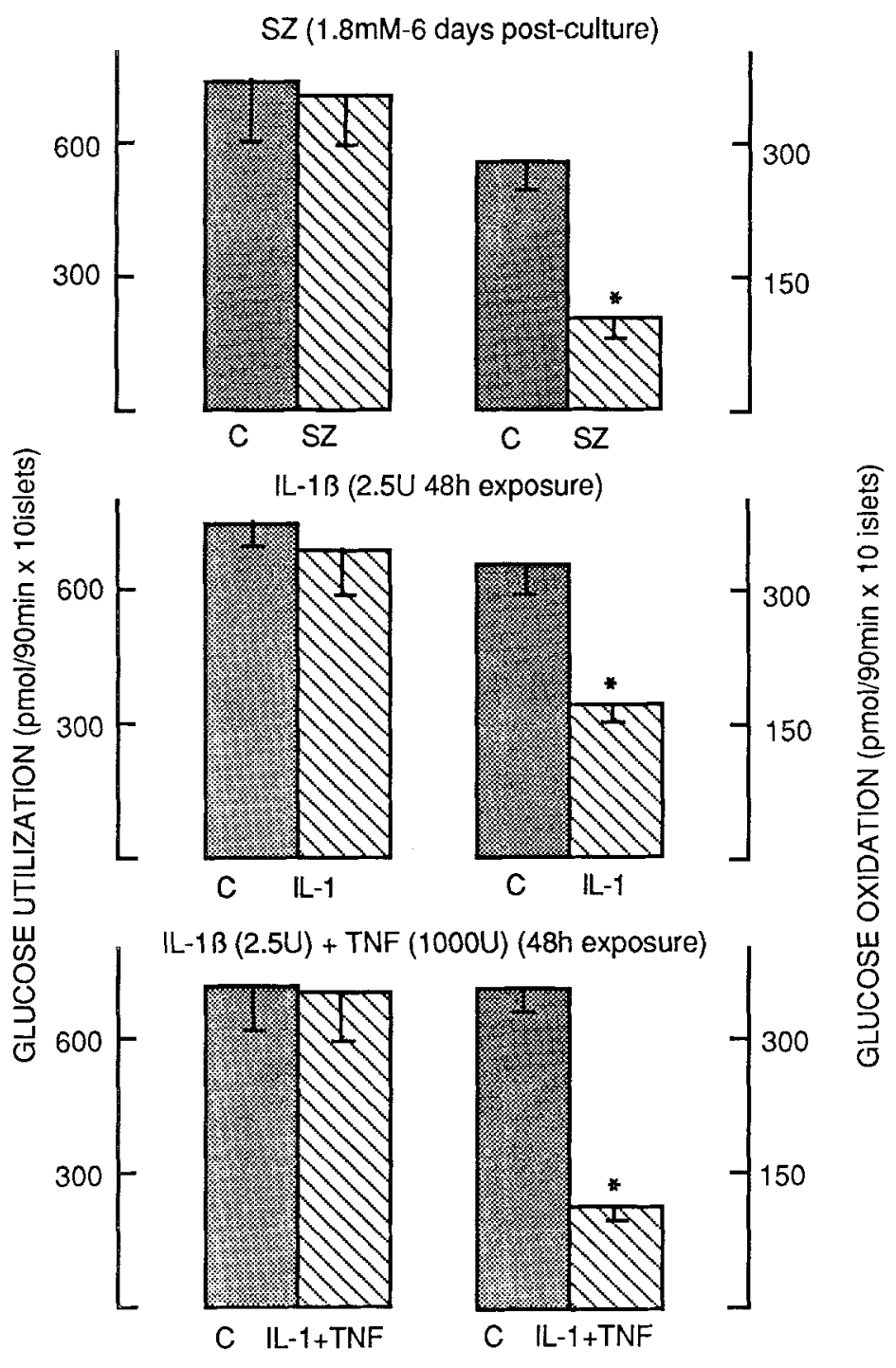

Figure 1. D-glucose metabolism in islets 6 days efter exposure to streptozotocin (SZ, $1.8 \mathrm{mM}$, mouse islets), $48 \mathrm{~h}$ exposure to interleukin-1ß (IL-1B, $2.5 \mathrm{U} / \mathrm{ml}$, rat islets) or a combination of IL-1B plus tumor necrosis factor (TNF, $1000 \mathrm{U} / \mathrm{ml}$, rat islets). The measurements of the $\mathrm{D}-\left[5^{-3} \mathrm{H}\right]$ glucose utilization rates (left) provide an estimate of the glycolytic pathway, while the D-[6-14 C]glucose oxidation (right) measures the mitochondrial oxidation of glucose. Data adapted from references 14 and 15. 
present similar rates of insulin release immediately after islet isolation and after several days in tissue culture $(23,81)$. Under these culture conditions, it was also shown that glucose concentrations in the range of 16.7 to $28 \mathrm{mM}$ did not induce any impairment in B-cell function $(23,81)$. As a whole, these conflicting in vitro observations raise the possibility that the described deleterious effects of glucose in vitro may be the result of specific culture conditions, rather than representing a true physiological phenomenon.

This in vivo/in vitro discrepancy is puzzling, especially considering the fact that B-cell toxins like streptozotocin, alloxan, cyproheptadine and pentamidine, which impair Bcell function in vivo, also impair B-cell function in vitro (24). Two possible explanations can be outlined. The first is that the artificial environment in vitro is unable to reproduce the complex phenomenon observed in vivo. The second is that high glucose, as a single factor, may indeed be harmless to islets of Langerhans, whereas factors related to the metabolic dysfunction of diabetes, like free fatty acids and branched chain amino acids, in combination with hyperglycemia may contribute to the B-cell impairment observed in vivo. Recent data actually suggest that elevated freefatty acids can selectively inhibit glucose-induced insulin secretion (56). Finally, it must be also considered that different genetic backgrounds can modify the sensitivity of B-cells to the diabetic environment (41), making it difficult to generalize findings from one strain or species to another.

In the context of IDDM, the possibility should be also considered that high glucose can impair B-cell function through an exacerbation of the autoimmune assault to the islets. Indeed, culture of rat pancreatic islets at high glucose concentrations stimulates the expression of islet cell autoantigens, such as the $64000-\mathrm{Mr}$ protein (42), recently shown to be the enzyme glutamic acid decarboxylase (3). On the other hand, suppression of $B$-cell function reduces the expression of pancreatic monosialogangliosides, also considered as potential targets for the autoimmune assault to the B-cells (12).

\section{D.3. Possible repair mechanisms activated by the B-cells}

The findings in vitro that dispersed B-cells $(50)$ or intact islets (18) are able to survive and even recover their functional activity after some cytotoxic assaults suggest that these cells possess a capacity to activate repair mechanisms after injury. These observations are corroborated by recent findings that islets isolated from pre-diabetic NOD mice (an animal model of autoimmune IDDM) are functionally suppressed immediately after isolation, but can recover their function after one week in culture (64).

So far, very little is known about the nature of the putative repair mechanisms activated by the B-cells after injury. One of the well characterized stress responses of 
eukaryotic and prokaryotic cells is the synthesis of a group of proteins denominated heat shock proteins (hsps) (65). It is generally accepted that the role of hsps is to protect cells in situations of stress and to enhance the ability of cells to recover after toxic or thermal injury. In mouse pancreatic islets, exposure to high temperatures $\left(42^{\circ} \mathrm{C}\right)$ induced a $4-10$-fold increase in the hsps 70 and 90 , which was paralelled by a subsequent functional recovery of these islets (74). Furthermore, exposure of murine islets to IL-1 also induced an increased synthesis of a protein with a molecular weight around $70 \mathrm{KDa}(32)$. This protein was recently confirmed, by western blot analysis, to be the murine hsp $70(21,83)$. Interestingly, islets exposed to IL-1 for $48 \mathrm{~h}$ are also able to recover their function, provided that they are cultured for a subsequent 6-7 days period in the absence of the cytokine (17). These observations suggest that, as observed in other cell systems, hsps can be of significance for the repair of injured Bcells.

\section{ACKNOWLEDGEMENTS}

We thank A. Snellman for careful typing of the manuscript. Work by the authors included in this review was supported by the Swedish Medical Research Council (12X-109, 12X-8273, 12X-9237), the Swedish Diabetes Association, the Nordic Insulin Fund, the Novo Company, the Torsten and Ragnar Söderberg Foundation, the Magnus Bergvall Fund, the Family Ernfors Foundation, the Juvenile Diabetes Foundation International, the Åke Wiberg Fund and the Uppsala University.

\section{REFERENCES}

1. Andersson, A., Westman, J. \& Hellerström, C.: Effects of glucose on the ultrastructure and insulin biosynthesis of isolated mouse pancreatic islets maintained in tissue culture. Diabetologia 10:743-753, 1974.

2. Arkhammar, P., Nilsson, T., Welsh, M., Welsh, N. \& Berggren, P.-O.: Effects of protein kinase $C$ activation on the regulation of the stimulus-secretion coupling in pancreatic B-cells. Biochem J 264:207-215, 1989.

3. Baekkeskov, S., Aansteot, H.-J., Christgan, S., Reetz, A., Solimena, M., Cascalho, M., Folli, F., Richter-Olesen, H. \& Camilli, P.D.: Identification of the 64K autoantigen in insulin-dependent diabetes as the GABA-synthesizing enzyme glutamic acid decarboxylase. Nature 347:151-156, 1990.

4. Berggren, P.-O., Hallberg, A., Welsh, N., Arkhammar, P., Nilsson, T. \& Welsh, M.: Transfection of insulin-producing cells with a transforming c-Ha-ras oncogene stimulates phospholipase C activity. Biochem J 259:701-707, 1989.

5. Bernstein, H.D., Poritz, M.A., Strub, K., Hoben, P.J., Brenner, S. \& Walter, P.: Model for signal sequence recognition from amino acid sequence of $54 \mathrm{~K}$ subunit of signal recognition particle. Nature 340:482-486, 1989.

6. Berridge, M.J. \& Irvine, R.F.: Inositol phosphates and cell signalling. Nature 341:197-205, 1989. 
7. Bone, A., Swenne, I. \& Hellerström, C.: Effects of high glucose concentrations on the insulin biosynthesis of rat pancreatic islets maintained for extended periods in tissue culture. Diab Metab 7:259-263, 1981.

8. Bonner-Weir, S., Trent, D.F. \& Weir, G.C.: Partial pancreatectomy in the rat and a subsequent defect in glucose-induced insulin release. J Clin Invest 71:15441553, 1983.

9. Brunstedt, J. \& Chan, S.J.: Direct effect of glucose on the preproinsulin mRNA level in isolated pancreatic islets. Biochem Biophys Res Commun 106:13831389, 1982.

10. Coleman ,D.L.: Obesity and diabetes: two mutant genes causing diabetesobesity syndromes in mice. Diabetologia 14:141-148, 1978.

11. Cook, D.L. \& Hales, C.N.: Intracellular ATP directly blocks $\mathrm{K}^{+}$channels in pancreatic B-cells. Nature 311:271-273, 1984.

12. Dotta, F., Ziegler, R., O'Neil, J.J., Hayak, R.C., Eisenbarth, G.S. \& Appel M.C.: Islet autoimmunity: identification and initial characterization of a metabolically regulable pancreatic ganglioside. Diabetologia 32:483A, 1989.

13. Eisenbarth, G.S.: Type I diabetes mellitus: a chronic autoimmune disease. $\mathrm{N}$ Engl J Med 314:1360-1368, 1986

14. Eizirik, D.L.: Interleukin-1 induced impairment in pancreatic islet oxidative metabolism of glucose is potentiated by tumor necrosis factor. Acta Endocrinol 119:321-325, 1988.

15. Eizirik, D.L., Sandler, S., Sener, A. \& Malaisse, W.J:. Defective catabolism of Dglucose and L-glutamine in mouse pancreatic islets maintained in culture after streptozotocin exposure. Endocrinology 123:1001-1007, 1988.

16. Eizirik, D.L., Sandler, S., Welsh, N. \& Hellerström, C.: Preferential reduction of insulin production in mouse pancreatic islets maintained in culture after streptozotocin exposure. Endocrinology 122:1242-1249, 1988.

17. Eizirik, D.L., Strandell, E., Bendtzen, K. \& Sandler, S.: Functional characteristics of rat pancreatic islets maintained in culture following exposure to human interleukin-1. Diabetes 37:916-919, 1988.

18. Eizirik, D.L. \& Sandler, S.: Function and metabolism of pancreatic B-cells maintained in culture following experimentally induced damage. Pharmacol Toxicol 65:163-168, 1989.

19. Eizirik, D.L. \& Sandler, S.: Sustained exposure of toxically damaged mouse pancreatic islets to high glucose does not increase B-cell dysfunction. J Endocrinol 123:47-51, 1989.

20. Eizirik, D.L., Sandler, S., Hallberg, A., Bendtzen, K., Sener, A. \& Malaisse, W.J.: Differential sensitivity to $B$-cell secretagogues in cultured rat pancreatic islets exposed to human interleukin-1B. Endocrinology 125:752-759, 1989.

21. Eizirik, D.L., Welsh, M., Strandell, E., Welsh, N. \& Sandler, S.: Interleukin-1B depletes insulin messenger RNA and increases the heat shock protein hsp70 in mouse pancreatic islets without impairing the glucose metabolism. Endocrinology 127:2290-2297, 1990.

22. Eizirik, D.L., Bendtzen, K. \& Sandler, S.: Short exposure of rat pancreatic islets to interleukin- $1 B$ induces a sustained but reversible impairment in $B$-cell function. This effect is influenced by protease activation, gene transcription and protein synthesis. Endocrinology (In press), 1991. 
23. Eizirik, D.L., Strandell, E. \& Sandler, S.: Prolonged exposure of pancreatic islets isolated from "pre-diabetic" non-obese diabetic mice to a high glucose concentration does not impair Beta-cell function. Diabetologia (In press), 1990.

24. Fischer, L.J.: Drugs and chemicals that produce diabetes. Trends Pharmacol Sci 6:72-75, 1985.

25. Ganda, O.P., Srikanta, S., Brink, S.J., Morris, M.A., Gleason, R.E., Soeldner, J.S. \& Eisenbarth, G.S.: Differential sensitivity to B-cell secretagogues in "early" Type 1 diabetes mellitus. Diabetes 33:516-521, 1984.

26. Giddings, S.J., Chirgwin, J. \& Permutt, M.A.: Effects of glucose on proinsulin messenger RNA in rats in vivo. Diabetes 31:624-629, 1982.

27. Hammonds, P., Beggs, M., Beresford, G., Espinal, J., Clarke, J. \& Mertz, R.J.: Insulin-secreting B-cells possess specific receptors for interleukin-1ß. FEBS Lett 261:97-100, 1990.

28. Hedeskov, C.J.: Mechanisms of glucose-induced insulin secretion. Physiol Rev 60:442-508, 1980.

29. Hellerström, C. \& Swenne, I.: Growth pattern of pancreatic islets in animals. In: The Diabetic Pancreas (ed. Volk B.W. \& Arquilla E.R.), pp. 53-79, Plenum, New York, 1985.

30. Hellerström, C., Swenne, I. \& Eriksson,U.J.: Is there an animal model for gestational diabetes? Diabetes 34 (Suppl. 2):28-31, 1985.

31. Hellerström, C., Swenne, I. \& Andersson, A.: Islet cell replication and diabetes. In: The Pathology of the Endocrine Pancreas in Diabetes (ed. Lefèbvre P.J. \& Pipeleers D.), pp. 142-165, Springer-Verlag, Heidelberg, 1988.

32. Helquist, S., Hansen, B.S., Johannesen, J., Andersen, H.U., Nielsen, J.H., \& Nerup, J.: Interleukin 1 induces new protein formation in isolated rat islets of Langerhans. Acta Endocrinol 121:136-140, 1989.

33. Hershey, J.W.B.: Protein phosphorylation controls translation rates. J Biol Chem 264:20823-20826, 1989.

34. Howell, S.L. \& Bird, G.S.J.: Biosynthesis and secretion of insulin. Br Med Bull 45:19-36, 1989.

35. Hughes, J.H., Colca, J.R., Easom, R.A., Turk, J. \& McDaniel, M.L.: Interleukin 1 inhibits secretion from isolated rat pancreatic islets by a process that requires gene transcription and mRNA translation. J Clin Invest 86: 856-863, 1990.

36. Itoh, N. \& Okamoto, H.: Translational control of proinsulin synthesis by glucose. Nature 283:100-102, 1980.

37. Jansson, L. \& Hellerström, C.: Glucose-induced changes in pancreatic islet blood flow mediated by central nervous system. Am J Physiol 251:E644-E647, 1986.

38. Jansson, L.: Glucose stimulation of pancreatic islet blood flow by redistribution of the blood flow within the whole pancreatic gland. Pancreas 3:409-412, 1988.

39. Kikkawa, U. \& Nishizuka, Y.: The role of protein kinase $C$ in transmembrane signalling. Annu Rev Cell Biol 2:149-178, 1986.

40. Klöppel, G., Löhr, M., Hablich, K., Oberholzer, M. \& Heitz, P.U.: Islet pathology and pathogenesis of type 1 and type 2 diabetes mellitus revisited. Sur Synth Path Res 4:110-125, 1985.

41. Korsgren, O., Jansson, L., Sandler, S. \& Andersson, A.: Hyperglycemia-induced $B$ cell toxicity. The fate of pancreatic islets transplanted into diabetic mice is dependent on their genetic background. J Clin Invest 86:2161-2168, 1990. 
42. Kämpe, O., Andersson, A., Björk, E., Hallberg, A. \& Karlsson, F.A.: High glucose stimulation of $64,000-\mathrm{Mr}$ islet cell autoantigen expression. Diabetes 38:13261328, 1989.

43. Mandrup-Poulsen, T., Bendtzen, K., Dinarello, C.A. \& Nerup, J.: Human tumor necrosis factor potentiates human interleukin 1-mediated rat pancreatic B-cell cytotoxicity. J Immunol 139:4077-4082, 1987.

44. Mandrup-Poulsen, T., Egeberg, J., Nerup, J., Bendtzen, K., Nielsen, J.H \& Dinarello, C.A.: Ultrastructural studies of time course and cellular specificity of interleukin-1 mediated islet cytotoxicity. Acta Pathol Microbiol Immunol Scand (C) $95: 55-63,1987$.

45. Meglasson, M.D. \& Matschinsky, F.M.: Pancreatic islet glucose metabolism and regulation of insulin secretion. Diabetes/Metab Rev 2:163-214, 1986.

46. Nerup, J. \& Mandrup-Poulsen, T.: On the pathogenesis of insulin-dependent diabetes mellitus (IDDM). Transplant Proc 28:1507-1508, 1986.

47. Nielsen, D.A., Welsh, M., Casadaban, M.J. \& Steiner, D.F.: Control of insulin gene expression in pancreatic B-cells and in an insulin producing cell line, RIN$5 F$ cells. Effects of glucose and cyclic AMP on the transcription of insulin mRNA. J Biol Chem. 260:13585-13589, 1985.

48. Nielsen, J.H.: Effects of growth hormone, prolactin and placental lactogen on insulin content and release and deoxyribonucleic acid synthesis in cultured pancreatic islets. Endocrinology 110:600-608, 1982.

49. Nielsen, J.H.: Mechanisms of pancreatic B-cell growth and regeneration. Exp Clin Endocrinol 93:277-285, 1989.

50. Pipeleers, D. \& Van de Winkel, M.: Pancreatic B cells possess defense mechanisms against cell-specific toxicity. Proc Natl Acad Sci USA 83:5267$5271,1986$.

51. Portha, B., Blondel, O., Serradas, P., McEvoy, R.C., Giroix, M.-H,. Kergoat, M. \& Bailbe $D$.: The rat models of non-insulin dependent diabetes induced by neonatal streptozotocin. Diabet Metab 15:61-75, 1989.

52. Pukel, C., Baquerizo, H. \& Rabinovitch, A.: Destruction of rat islet cell monolayers by cytokines. Synergistic interactions of interferon-g, tumor necrosis factor, lymphotoxin, and interleukin 1. Diabetes 37:133-136, 1988.

53. Rabinovitch, A., Sumoski, W., Rajotte, R.V. \& Warnock, G.L.: Cytotoxic effects of cytokines on human pancreatic islets in monolayer culture. $J$ Clin Endocrinol Metab 71:152-156, 1990.

54. Rosseti,L., Giaccari, A. \& De Fronzo, R.A.: Glucose toxicity. Diabetes Care 13:610-630, 1990.

55. Rorsman, P., Arkhammar, P., Bokvist, K., Hellerström, C., Nilsson, T., Welsh, M., Welsh, N. \& Berggren, P.O.: Failure of glucose to elicit a normal secretory response in fetal pancreatic beta cells results from glucose insensitivity of the ATP-regulated $\mathrm{K}^{+}$channels. Proc Natl Acad Sci USA 86:4505-4509, 1989.

56. Sako, Y. \& Grill, V.: A $48 \mathrm{~h}$ lipid infusion in the rat time-dependently inhibits glucose-induced insulin secretion and $B$ cell oxidation through a process likely coupled to fatty acid oxidation. Endocrinology 127:1580-1589, 1990.

57. Samols, E. \& Stagner, J.I.: Intra-islet regulation. Am J Med 28:31-35, 1988.

58. Sandler, S., Andersson, A. \& Hellerström, C.: Inhibitory effects of interleukin 1 on insulin secretion, insulin biosynthesis, and oxidative metabolism of isolated rat pancreatic islets. Endocrinology 121:1424-1431, 1987. 
59. Sandler, S., Bendtzen, K., Borg, L.A.H., Eizirik, D.L., Strandell, E. \& Welsh, N. Studies on the mechanisms causing inhibition of insulin secretion in rat pancreatic islets exposed to human interleukin-1 $B$ indicate a perturbation in the mitochondrial function. Endocrinology 124:1492-1501, 1989

60. Sandler, S., Bendtzen, K., Eizirik, D.L. \& Welsh, M.: Interleukin-6 affects insulin secretion and glucose metabolism of rat pancreatic islets in vitro. Endocrinology 126:1288-1294, 1990.

61. Sener, A. \& Malaisse, W.J.: Stimulation by D-glucose of mitochondrial oxidative events in islet cells. Biochem J 246:89-95, 1987.

62. Spinas, G.A., Hansen, B.S., Linde, S., Kastern, W., Mølvig, J., Mandrup-Poulsen, T., Dinarello, C.A., Nielsen, J.H. \& Nerup, J.: Interleukin 1 dose-dependently affects the biosynthesis of (pro)insulin in isolated rat islets of Langerhans. Diabetologia 30:474-480, 1987.

63. Strandell, E., Eizirik, D.L., Korsgren, O. \& Sandler, S.: Functional characteristics of cultured mouse pancreatic islets following exposure to different streptozotocin concentrations. Molec Cell Endocrinol 59:83-91, 1988.

64. Strandell, E., Eizirik, D.L. \& Sandler, S.: Reversal of B-cell suppression in vitro in pancreatic islets isolated from nonobese diabetic mice during the phase preceding insulin-dependent diabetes mellitus. J Clin Invest 85:1944-1950, 1990-

65. Subjeck, J.R. \& Shyy, T.T.: Stress protein systems of mammalian cells. Am J Physiol 250:C1-C17, 1986.

66. Svensson, C. \& Hellerström, C.: Long-term effects of high glucose concentrations in vitro on the oxidative metabolism and insulin production of isolated rat pancreatic islets. Metabolism (In press), 1991.

67. Swenne, I.: Role of glucose in the in vitro regulation of cell cycle kinetics and proliferation in fetal pancreatic B-cells. Diabetes 31:754-760, 1982.

68. Swenne, I., Hill, D.J., Strain, A.J. \& Milner, R.D.G.: Effects of human placental lactogen and growth hormone on the production of insulin and somatomedin C/insulin-like growth factor 1 on the DNA replication of fetal rat islets of Langerhans in tissue culture. Endocrinology 122:214-218, 1988.

69. Swenne, I., Hill, D.J., Strain, A.J. \& Milner, R.D.G.: Growth hormone regulation by somatomedin C/insulin-like growth factor I production and DNA replication in fetal islets in tissue culture. Diabetes 36:288-294, 1987.

70. Swenne, I., Heldin, C.H., Hill, D.J. \& Hellerström, C.: Effects of platelet-derived growth factor and somatomedin C/insulin-like growth factor I on the DNA replication of fetal rat islets of Langerhans in tissue culture. Endocrinology 122:214-218, 1988.

71. Weir, G.C., Leahy, J.L. \& Bonner-Weir, S.: Experimental reduction of B-cell mass: implications for the pathogenesis of diabetes. Diabetes/Metab Rev 2:125-61, 1986.

72. Welsh, M., Nielsen, D.A., MacKrell, A.J. \& Steiner, D.F.: Control of insulin gene expression in pancreatic B-cells and in an insulin producing cell line, RIN-5F. Regulation of insulin mRNA stability. J Biol Chem 47:299-303, 1985.

73. Welsh, M., Scherberg ,N., Gilmore, R. \& Steiner, D.F.: Translational control of insulin biosynthesis. Evidence for regulation of elongation, initiation and signalrecognition-particle-mediated tranlational arrest by glucose. Biochem J 235:459$567,1986$. 
74. Welsh, M., Eizirik, D.L. \& Strandell, E.: Heat shock treatment of mouse pancreatic islets results in a partial loss of islet cells but no remaining functional impairment among the surviving B-cells. J Mol Endocrinol 1:27-31, 1988.

75. Welsh, M, Welsh, N., Nilsson, T., Arkhammar, P., Pepinsky, R.B. Steiner, D.F. \& Berggren, P.-O.: Stimulation of islet beta-cell replication by oncogenes. Proc Natl Acad Sci USA 85:116-120, 1988.

76. Welsh, M.: Glucose regulation of insulin gene expression. Diab Metab 15:367371, 1989.

77. Welsh, M., Claesson-Welsh, L., Hallberg, A., Welsh, N., Betsholtz, C., Arkhammar, P., Nilsson, T., Heldin, C.-H. \& Berggren, P.-O.: Coexpression of the platelet-derived growth factor (PDGF) $B$ chain and the PDGF $B$ receptor in isolated pancreatic islet cells stimulates DNA synthesis. Proc Natl Acad Sci USA 87:5807-5811, 1990.

78. Welsh, N., Welsh, M., Steiner, D.F. \& Hellerström, C.: Mechanisms of leucin- and theophylline-stimulated insulin biosynthesis in isolated rat pancreatic islets. Biochem J 246:245-248, 1987.

79. Welsh, N., Svensson, C. \& Welsh, M.: Content of adenine nucleotide translocator mRNA in insulin-producing cells of different functional states. Diabetes 38:13771380, 1989.

80. Welsh, N.: A role for polyamines in glucose-stimulated insulin-gene expression. Biochem J 271:393-397, 1990.

81. Welsh, N. \& Hellerström, C.: In vitro restoration of insulin production in islets from adult rats treated neonatally with streptozotocin. Endocrinology 126:1842-1848, 1990.

82. Welsh, N., Bendtzen, K. \& Sandler, S.: Influence of protease on inhibitory and stimulatory effects of interleukin $1 B$ on pancreatic B-cell function. Diabetes (In press), 1991.

83. Welsh, N., Welsh, M., Lindquist, S., Eizirik, D.L., Bendtzen, K. \& Sandler, S.: Interleukin-1 $B$ increases the biosynthesis of the heat shock protein hsp 70 and selectively decreases the biosynthesis of five proteins in rat pancreatic islets. Autoimmunity (In press), 1991.

84. Öberg, C., Welsh, N., Svanholm, S. \& Welsh, M.: GTP-binding proteins are involved in stimulation of islet insulin biosynthesis. Diabetologia 32:525A, 1989.

Address for correspondence:

Professor Claes Hellerström

Department of Medical Cell Biology

$\mathrm{BMC}$

Box 571

S-751 23 Uppsala

Sweden 